IRSH 58 (2013), pp. 463-49I doi:10.1017/So0208590I 3000 I 87

(C) 2013 Internationaal Instituut voor Sociale Geschiedenis

\title{
Brotherhood From a Distance: Americanization and the Internationalism of the Knights of Labor*
}

\author{
STEVEN PARFITT \\ Department of History, University of Nottingham \\ University Park, Nottingham NG7 2 RD, UK \\ E-mail: ahxsp@nottingham.ac.uk
}

\begin{abstract}
Aвstract: The Noble and Holy Order of the Knights of Labor was the largest American labour organization of the nineteenth century. But while scholars have charted its history in North America they have largely failed to explore the Order's history elsewhere, even though the organization also boasted members in Europe, Australasia, and Africa. This article is designed as part of a wider "transnationalization" of American labour history, and analyses the reasons that drove the Order's leaders towards their international growth. The leaders of the Knights of Labor sent organizers around the world not only because of their attachment to the idea of Universal Brotherhood, but also as a way to limit immigration to the United States. This synthesis of seemingly incompatible ideas reflected their desire to "Americanize" the rest of the world, by protecting living standards at home, raising them elsewhere to American standards, and exporting American-style republican institutions abroad.
\end{abstract}

In I 86I, even as seceding states tore the United States apart, a Philadelphian tailor wrote a friend in New York of a dream that occupied his thoughts. "I do not claim to be gifted with the power of prophesy", he began,

But I can see ahead of me an organization that will cover the globe. It will include men and women of every craft, creed and color: It will cover every race worth saving. It will come in my time, I hope. Its groundwork will be secrecy, its rule obedience, and its guiding star mutual assistance. It will make labor honourable and profitable and lessen its burdens; it will make idleness a crime, render wars impossible, and obliterate national lines. ${ }^{\text {I }}$

* I would like to thank Professor Chris Wrigley and Dr Nick Baron of the University of Nottingham, and Dr Paul Taillon and Dr Catherine Balleriaux of the University of Auckland, for reading earlier versions of this article and offering helpful suggestions for its improvement. All mistakes are mine alone.

I. Proceedings of the General Assembly of the Knights of Labor (Philadelphia, I897), n.p. [hereafter Proceedings of the GA]. 
The dreamer was Uriah Stephens, first founding father the Noble and Holy Order of the Knights of Labor. The Knights, combining the forms and rituals of a fraternal order with the functions of trade unions and the programme of political reform, have long been recognized as the pre-eminent labour organization of the Gilded Age. From early beginnings at Philadelphia in I869, not eight years after Stephens's dream, the Knights rode the great wave of strikes, militancy, and working-class political action of the mid-I 880 s that historians term the Great Upheaval. In 1886 they reached nearly I million members, many of them, to a degree unprecedented in American labour history, women or black workers. Thereafter they fell into decline, wracked by internal disputes, employer opposition, and competition from rival trade unions. By the mid-i 890 s they were a spent force. In I9I7 the few surviving members brought the Order's existence finally to an end, storing its remaining property in a leaky shed behind an office in Washington DC. ${ }^{2}$

This great drama, as it played out in the United States, has justly received the attention of all subsequent generations of labour historians. But what of Stephens's dream, particularly his hope that his organization might cover the globe? The Knights, after all, did establish their assemblies in England, Scotland, Wales, Ireland, Australia, New Zealand, France, Belgium, South Africa, Italy, and possibly Germany, Mexico, and the Scandinavian states as well. Some of these outposts were far from insignificant. British Knights, for instance, probably numbered at least I 0,000 in all. Those in Belgium may have been double or even triple that figure. ${ }^{3}$ New Zealand Knights, as Robert Weir has explained, reached into five figures and exerted a tremendous influence over the social and political legislation - from the landmark Arbitration and Conciliation Act to women's suffrage and old-age pensions - that made turn-of-the-century New Zealand the "social laboratory of the world". ${ }^{4}$

While other labour organizations also organized around the globe, such as the British Amalgamated Societies of Engineers and Carpenters and Joiners, none matched the Knights in terms of the numbers or the range of industries that they organized abroad..$^{5}$ Indeed, at least until if not also for several years after the first Congress of the Second International, the

2. Norman Ware, The Labor Movement in the United States, 1865-1895: A Study in Democracy (New York, 1964), p. xi.

3. Henry Pelling, "The Knights of Labor in Britain, I880-I90I", Economic History Review, 9 (1956), pp. 313-331; I893-I894 Royal Commission on Labour: Foreign Reports, IV (London, I893), pp. I3-I 4 .

4. Robert Weir, Knights Down Under: The Knights of Labour in New Zealand (Cambridge, 2009).

5. Richard T. Ely, "Economic Internationalism", The Chautauquan (February I890), pp. 538-542; James B. Jeffreys, The Story of the Engineers (London, I945), p. 6I. 
Order was probably the most successful international labour organization in the world. ${ }^{6}$ Leading Knights, at least, certainly saw their Order as more than simply American. Terence Powderly, General Master Workman (GMW) of the Knights from I878 to I 893, insisted at near the height of the Order's numbers and notoriety in I 887 that "the motto of our organization, 'An injury to one is the concern of all,' is worldwide in its application".?

Yet aside from Robert Weir's invaluable study of the Order in New Zealand, there are only scattered references in historical writing to the Knights' activities around the world. ${ }^{8}$ This is partly a reflection of the fact that their Order maintained a level of secrecy throughout its existence that makes the task of historical reconstruction more difficult. This is particularly true outside North America where available primary sources are, as Weir describes them, "slender threads framing suggestive holes". But these scattered historiographical references are also a barometer of scholarly inattention. Truly, as Marcel van der Linden has suggested, we should more closely study the Order's overseas achievements as part of a wider and long overdue "transnationalization" of US labour history. ${ }^{\circ}$

This essay, however, deals less with these achievements themselves and more with the reasons that led Knights abroad in the first place. Many

6. J.H.M. Laslett, "Haymarket, Henry George, and the Labor Upsurge in Britain and America During the Late I880s", International Labor and Working-Class History, 29 (1986), pp. 68-82; Weir, Knights Down Under, p. 206.

7. Reynolds's Newspaper, 2 October i 887.

8. A useful but incomplete list of the Order's assemblies around the world is Jonathan Garlock, Guide to the Local Assemblies of the Knights of Labor (Westport, CT, 1982). A short and not exhaustive list of scholarship which touches on the Knights outside North America includes, for Britain: Pelling, "Knights of Labor in Britain"; R. Bean, "A Note on the Knights of Labour in Liverpool", Labor History, I 3 (1972), pp. 68-78; James D. Young, "Changing Images of American Democracy and the Scottish Labour Movement", International Review of Social History, i 8 (1973), pp. 69-89. For Australia and New Zealand, see: L.G. Churchward, "The American Influence on the Australian Labour Movement", Historical Studies: Australia and New Zealand, 5 (1953), pp. 258-277; Bob James, "The Knights of Labor and Their Context", found at: http://www.takver.com/history/secsoco2.htm; Bruce Scates, "Wobblers': Single Taxers in the Labour Movement, Melbourne 1889-1899", Historical Studies, 2 г:83 (1984), pp. 174-196; idem, “Millenium or Pandemonium?': Radicalism in the Labour Movement, Sydney, I 889-1 899", Labour History, 50 (1986), pp. 72-94; Herbert Roth, “American Influences on the New Zealand Labour Movement”, Australian Historical Studies, 9 (I96I), pp. 4I 3-420; idem, "The Distribution of New Zealand Radicalism: 1890-1957", New Zealand Geographer, Is (1959), pp. 76-83; For Belgium, see: Leon Watillon, The Knights of Labour in Belgium (Los Angeles, CA, 1959). For South Africa, see: Robert Vicat Turrell, Capital and Labour on the Kimberley Diamond Fields (Cambridge, 1987). For France, see: Maurice Dommanget, La Chevalerie du Travail Française, I893-I9I I (Lausanne, I967).

9. Weir, Knights Down Under, p. 220.

ı०. Marcel van der Linden, "Transnationalizing American Labor History", Journal of American History, 86 (1999), pp. 1078-1092. 
unionists in the United States and elsewhere shared some version of Stephens's dream. But few tried, as the Knights did, to give it practical shape. My focus, in other words, lies in what drove North American Knights to organize outside their home continent. Through analysis of the reasons behind these attempts we enrich the study of labour internationalism, a subject largely concerned with Europe and not the New World. We better understand the world and concerns of late-nineteenthcentury workers. Finally, we place the Order in better international - not to mention American - perspective.

Some contemporaries of the Knights saw their overseas work as simply an attempt to redress their post-I 886 decline in the United States, or even simply as a crutch for the (undeniable) vanity of Powderly and his associates. ${ }^{\text {I }}$ These accusations contain at least a grain of truth. But the story of the Order as an international body predates its decline by several years, for as early as I 884 the window-glass workers of Local Assembly 300 had organized their fellow craftsmen in England, Belgium, Italy, and possibly in France and Germany as well. We must therefore look elsewhere for better and more complete explanations of why the Order spread across many countries and continents where so few contemporary organizations did likewise.

Knights found the impetus behind their international expansion, I argue, from two main impulses. The first was the product of the globalized world in which they lived. The late nineteenth century witnessed unprecedented migration on a global scale, and many of these migrants aimed for the United States. Knights, as well as other American trade unionists, sought to restrict or at least to regulate this immigration which, they believed, could pose an existential threat to labour organization in the New World if left unchecked. The second impulse came from the Order's founding principle, Universal Brotherhood. This potent idea emphasized solidarity amongst workers of all backgrounds, colours, creeds, crafts, and even of both genders, and had very strong international implications.

On the surface these two concerns might appear contradictory. Opposition to immigration does not seem to sit well with the idea of solidarity transcending all boundaries of race and origin. Knights, however, did not see these two beliefs as incompatible. On the one hand, they sought to regulate the flow of immigrants to the United States in order to maintain living standards and labour organization there. On the other, they sought to live up to their ideals of Universal Brotherhood. Organizing on an international scale promised to address both concerns, for by spreading their brotherhood around the world they would help workers overseas to improve their own conditions, and thus address the causes of the 
immigration that, if left unchecked, threatened the rights and dignity of labour at home and abroad.

Knights, I argue, sought to practise "brotherhood from a distance", helping workers elsewhere so as to prevent them from endangering workers at home. They also sought to reconcile nationalism with internationalism. This is a recurring theme in studies of labour internationalism, and increasing attention has been paid to the idea that these two abstract concepts were not always necessarily opposites. ${ }^{\mathrm{I} 2} \mathrm{Knights,}$ as we will see, combined a strong sense of American patriotism with a universalist credo. Again, they saw no contradiction here. American labour, they felt, enjoyed greater wages, working conditions, and political freedoms than elsewhere conditions they hoped and intended to extend beyond their continent. Just as they practised brotherhood from a distance they sought to Americanize the rest of world, harnessing nationalism in the service of internationalism for what they saw as the mutual benefit of all.

Like their views regarding immigrants and immigration or Universal Brotherhood, or their stances on issues of race or gender, to name only a few examples, this synthesis was not necessarily rigid or unchanging. Knights could rail against certain types of immigrants at one moment, for example, only to organize them the next. Powderly and other leading Knights could insist on the Order's doctrinal purity even as they gave different localities, and especially assemblies overseas, wide scope to adjust the Order's principles to local conditions. ${ }^{13}$ For practical reasons, in other words, Knights could meld or adapt any of their principles if by so doing they would encourage the spread of the Order and its broad message.

The same point applies to their "brotherhood from a distance". It is difficult to find in the Order's growth in Australia and New Zealand, for example, much concern about the dangers of immigration from those (sparsely populated) countries. But where Knights set up their first overseas assemblies - namely, in Europe - it was this synthetic "brotherhood from a distance" that provided the requisite push. In the same way it is important not to overestimate the homogeneity of opinion within the Order, for the Knights were famously heterogeneous in their views on everything from politics to industrial organization. Yet the leaders from Powderly down who led and oversaw the Order's international expansion had enough in common, ideologically and practically speaking, to make this kind of generalization work.

I 2. Two more recent examples of this are Susan Milner, The Dilemmas of Internationalism: French Syndicalism and the International Labour Movement, 1900-19I4 (New York, 1990); Geert van Goethem, The Amsterdam International: The World of the International Federation of Trade Unions (IFTU), I9I3-I945 (London, 2006).

I3. For the Order's global adaptability see especially Weir, Knights Down Under; and Gregory S. Kealey and Bryan D. Palmer, Dreaming of What Might Be: The Knights of Labor in Ontario, I880-1900 (Cambridge, I982). 
Having noted these important caveats this article proceeds in three parts. The first concerns immigration, and the ways that Knights could and did respond to what they saw as its dangers, from lobbying for restrictions on certain immigrants to organizing them in their home countries. The second introduces Universal Brotherhood, its origins and its international implications, and intersects with concerns over immigration to show how Knights did, in general, aim to practise this brotherhood from the other side of the Atlantic and Pacific Oceans. The third and final part addresses the connection of this brotherhood from a distance with what amounted, in many Knights' imaginations at least, to what they hoped would be their Americanization of the rest of the world.

\section{IMMIGRATION AND INTERNATIONALISM}

To understand the internationalism of the Knights of Labor we must begin with one of the great forces moulding and created by Victorian-era capitalism. In the last decades of the nineteenth century the reach of capital spread far beyond the borders of imperial Europe, and sent the whole world into unprecedented movement. This was especially true for those living on the periphery of the industrial world, in southern and eastern Europe and eastern Asia in particular. Their economies were subject to drastic and tumultuous economic change, while it was widely known that in the industrial countries they could earn wages many times above what they could at home. ${ }^{I 4}$ The United States was one of the key receptacles of this influx of men and women. In four of the years between I905 and I9ro the annual total of immigrants exceeded a staggering I million people. But the acceleration of this immigration began in the I880s, when the Knights were at the peak of their strength. More than twice as many new arrivals entered the United States during this decade than in the I870s, averaging more than 500,000 each year. ${ }^{15}$

Along with this acceleration came changes in the composition of the new arrivals. A growing number of these immigrants came from southern and eastern Europe. ${ }^{16}$ As with the Chinese, American unionists viewed these "new" immigrants with suspicion at best. ${ }^{17}$ Powderly's testimony before an i 888 Congressional Committee on contract labour exemplified

I4. David Montgomery, The Fall of the House of Labor: The Workplace, the State, and American Labor Activism, I865-1925 (Cambridge, I989), pp. 70-82.

15. Report of the United States Immigration Commission I9II-I2, 4I vols (Washington DC, I9I I), III, pp. 4-5.

I6. Ibid., p. 8.

17. Joseph Gerteis, "The Possession of Civic Virtue: Movement Narratives of Race and Class in the Knights of Labor", American Journal of Sociology, 108 (2002), pp. 580-61 5, 591; Bruce Laurie, Artisans into Workers: Labor in Nineteenth-Century America (Urbana, IL, 1997), p. 197 . 


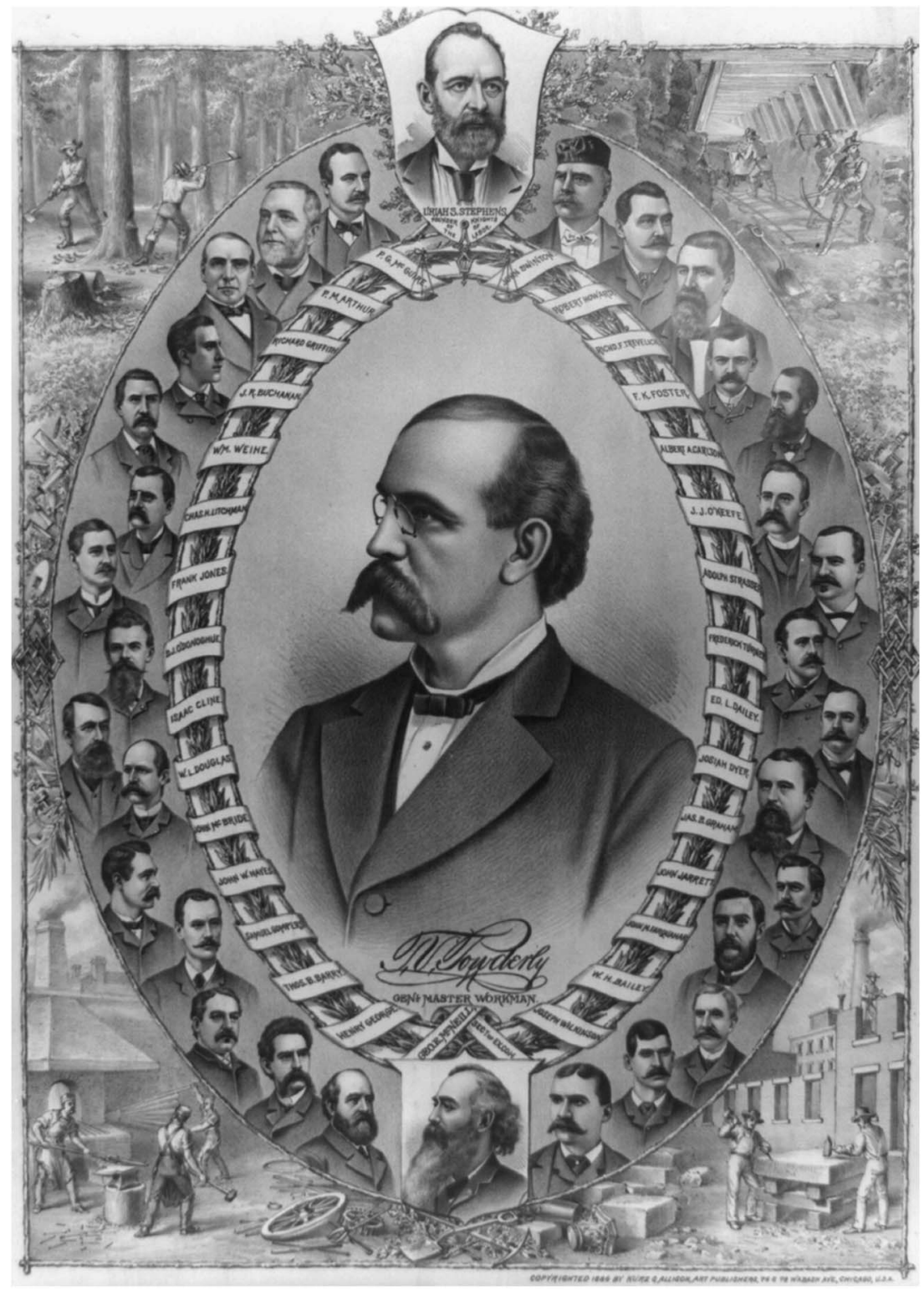

Figure I. The leaders of the Knights of Labor, as well as leaders of some non-affiliated trade unions, in 1886 , the year of their greatest numbers and power in the United States. Terence Powderly is in the centre, and Uriah Stephens (though he died in I882) is at the very top. Library of Congress: Prints and Photographs Division. Used with permission. 
these fears. The GMW drew sharp distinctions between older immigrants from western and northern Europe, who "came of their own free will and accord", and the squalor of Hungarian immigrants in the Pennsylvania coalfields. Of the latter, he claimed, nothing "would cause me to think" that these new immigrants "would make good American citizens; their lives are too low to make it". Depicting polygamous relationships caused by imbalances in the number of men and women in the mining camps, he added that their presence "has the tendency to degrade morals" ${ }^{18}$ Other Knights also drew similar conclusions, and the Journal of United Labor regularly emphasized the undesirability of the new immigrants compared with the old. ${ }^{19}$

Several overlapping concerns were at work here. Contract labour, as Powderly suggested, threatened to permit the return of slavery through the back door by chaining the immigrant to one great corporation or another, and using him or her as a weapon against free, independent labour. This found racial expression too. American workers had long denounced Chinese immigrants as the advance guard of a new form of American slavery. In the I 880 s, as Joseph Gerteis writes, immigrants from southern and eastern Europe were subject to the same kind of "racial closure" as the Chinese, in contrast to the "racial openness" which most Knights accorded to black workers. ${ }^{20}$ These two concerns were often conflated, with those subject to "racial closure" equated with unfree labour. Class worries found racial expression; racial prejudice was placed in class terms.

Yet the Knights rejected any community of interest with the nativist movement. The heirs of the Know-Nothings, the Order of United American Mechanics, and other nativist associations of the 1840 s experienced a remarkable revival in their fortunes in the $\mathrm{I} 880$ os. $^{2 \mathrm{I}}$ The most successful nativist organization, the American Protective Association, formed in 1887 in Clinton, Iowa, claimed in I894 a total of 2.5 million members, though later scholars have revised this number downward to between 100,000 and 500,000. ${ }^{22}$ Individual Knights could come close to endorsing nativistic rhetoric. The same John Hughes who organized an assembly in Wales told reporters that "the Knights of Labor is purely an

I 8. "Testimony of T.V. Powderly," Testimony Taken by the Select Committee of the House of Representatives to Inquire into the Alleged Violation of the Laws Probibiting the Importation of Contract Laborers, Paupers, Convicts, and other Classes (Washington DC, I 888), pp. 497-499. 19. For a detailed examination of these journals' attitudes towards the new immigrant, see especially Gerteis, "Possession of Civic Virtue". Also, in I 890 the name of the Journal of United Labor was changed to The Journal of the Knights of Labor.

20. Gerteis, "Possession of Civic Virtue", pp. $58 \mathrm{I}-582$.

21. John Higham, Strangers in the Land: Patterns of American Nativism, I860-1925 (New York, 1963), pp. 53-54.

22. Thomas J. Curran, Xenophobia and Immigration, I820-1930 (Boston, MA, I975), p. 105. 
American institution and anyone who has not sworn allegiance to this Government should not be allowed to come into the order". ${ }^{23}$ But the nativists, with their pungent amalgam of traditional anti-Catholicism and anti-radicalism, were anathema to the Knights. This hostility ran both ways. ${ }^{24}$ Many Knights were Catholics themselves. Their Order, however much Powderly wished otherwise, was also strongly identified with all the strikes of the Great Upheaval and with the anarchists of Haymarket Square. And Powderly, like other Knights, denounced the way that nativists fostered religious bigotry and other divisions amongst American workers. They were, he wrote, "doing the work of the bondholder, the usurer and the monopolist". ${ }^{25}$

This antipathy to nativism helps to better elucidate the Knights' stances toward immigrants and immigration. It is often said that the Knights of Labor fought capitalism but not the capitalist; it is equally true to say that they fought immigration, or at least certain kinds of immigration, without necessarily fighting the immigrant. For undeniably racist reasons Knights did enthusiastically support the I 882 Chinese Exclusion Act, though it was activists in California and the western territories who were most prominent in getting that Act through Congress. ${ }^{26}$ The next major piece of restrictionist legislation, the Alien Contract Law of I 855 , by contrast, owed much to the Order, and particularly the glassworkers of Local Assembly 300 (LA 300$){ }^{27}$ This law, as the name suggests, was not intended as a blanket ban on all immigration. It was instead designed to prevent generally skilled workers from arriving in the United States already under contract to particular employers. Many employers had already used this device to break strikes and, in the long term, to use what American workers saw as indentured labour to prevent the growth of labour organization.

$\mathrm{LA}_{3} 00$ had particularly strong reasons for seeing this Act passed. Technological change in continental glassworks lowered wages and employment for glassworkers there. American glass manufacturers sought to use this pool of skilled but unemployed foreign artisans to break LA 300 's stranglehold on the domestic supply of glassworkers. In I88 I

23. New York Times, 3 I August I 888.

24. K. Gerald Marsden, "Patriotic Societies and American Labor: The American Protective Association in Wisconsin", Wisconsin Magazine of History, 4I (1958), pp. 287-294; Curran, Xenophobia and Immigration, p. I02.

25. Journal of the Knights of Labor [hereafter JUL, along with the Journal of United Labor], I4 May i 89i.

26. John R. Commons et al., History of Labor in the United States, 4 vols (New York, I936), II, pp. $252-268$.

27. For the importance of Chinese exclusion in the development of later immigration restrictions, see especially Erika Lee, "The Chinese Exclusion Example: Race, Immigration, and American Gatekeeping, I882-1924", Journal of Ethnic History, 2 I (2002), pp. 36-62. 
and I 882, especially, the Assembly faced a number of severe challenges that required a decisive response. One member had already been expelled from the Assembly in I 880 for organizing contracted foreigners to break a strike. In 1882 the Assembly's Treasurer absconded with $\$ 4,000$ of its funds. The Assembly's almost total success in organizing or sending back foreign strike-breakers also came with a hefty financial bill. ${ }^{28}$ The costs of lobbying for immigration restrictions were minor by comparison, and it was largely due to LA300's unusually strong financial position, and largely through its urging, that the Order employed Ralph Beaumont as a sometime Washington lobbyist particularly concerned with restricting immigration. ${ }^{29}$

Knights thus sought to regulate immigration, in order to protect jobs and organization, and not to exclude all immigrants. There were naturally some exceptions to this rule, and not only the Chinese. The Window Glass Workers, as A.T. Lane writes, defined contract labour as "skilled workers imported from Europe under written contract to American employers". The Order's national leadership, Lane continues, "broadened the meaning to embrace unskilled workers too, and in particular penurious and so-called degraded unskilled workers originating in Southern and Eastern Europe" ${ }^{3 \circ}$ But even here the Order proved flexible. "Though Powderly was disgusted with the 'new immigrant' in the steel and coal regions, the Knights organized among all nationalities, races, creeds, and grades of skill", as Norman Ware observed. ${ }^{3 \mathrm{I}}$ The GMW and other leading Knights likewise insisted that their goal was the international regulation of labour and not knee-jerk restrictionism. "There is no know-nothingism in wise adjustment of the supply of labor to the demand", claimed an I 887 book prefaced and endorsed by Powderly. "There is no injustice; it is after all the working of nature's first law, self-preservation, which impels us to protect American labor, even at the expense of Europe." ${ }^{2}$

But these attitudes represent only the beginning of Knights' engagement with the problems of immigrants and immigration. Recent work on organized labour and immigration, most of which deals either with the late nineteenth or late twentieth centuries, write Janice Fine and Richard Tichenor, leave us "with rival views of a nativist and restrictionist

28. Charles Leinweber, Immigration and the Decline of Internationalism in the American Working Class Movement, I864-I9I9 (Berkeley, CA, 1968), p. 56; JUL, is December I880; is October I882; is January i 883.

29. Commons, History of Labour in the United States, II, p. 373.

30. A.T. Lane, Solidarity or Survival? American Labor and European Immigrants, 1830-1924 (New York, 1987), p. 62.

31. Ware, Labor Movement in the United States, p. xiv.

32. John Cameron Simonds and John T. McEnnis, The Story of Manual Labor in All Lands and Ages: Its Past Condition, Present Progress, and Hope for the Future (Chicago, IL, I887), p. 487. 
labor movement" in the former period and "an increasingly inclusive and pro-immigration one" in the latter. ${ }^{33}$ And studies of the earlier period generally end here, with legislative achievements tallied up and due notice taken of the gap between the Order's universalistic preaching and Knights' often xenophobic words and deeds. ${ }^{34}$ But here is where the story of the Order's internationalism only begins.

There were several roads leading from restricting immigrants to organizing them in their native lands. The first lay in the fact that, as Isaac Hourwich wrote in a contemporary attack on the restrictionist conclusions of the I9I I US Immigration Commission, foreign-born workers joined unions in proportionally higher numbers than those of American birth. ${ }^{35}$ The Knights were no exception, especially if we also include those, like Powderly, who were second-generation Americans. Immigrants, and those of immigrant stock, had access to a number of transnational networks that could facilitate the spread of the Order's message back home. They also brought their continued interest in their ancestral homes and its politics into the Order's local, district, and general assemblies. German-born Knights, for instance, issued a public manifesto and provided financial aid to the German Social Democrats in I887. Their agitation probably explains Powderly's claim before a Congressional Committee the next year that "we have laid the foundations for assemblies in Germany". ${ }^{36}$

But it was the Irish who proved most conspicuous here. Many Knights, from Powderly down, were of Irish ancestry or birth and numbered amongst the many Irish Americans who helped finance and lobby for the national cause of their brethren at home. Many of them saw, as did one contributor to the Journal of the Knights of Labor, that "the principles for which the Irish Nationalists are contending are practically the same as those held by the labor reformers in their struggle against capitalistic oppression". ${ }^{77}$ The rapturous welcome given to Michael Davitt at the I 887 General Assembly, one that he returned by serving briefly as an organizer in England, and even more briefly as the Master Workman of Birmingham's District Assembly 208, underlined this point. ${ }^{38}$

33. Janice Fine and Daniel Tichenor, "A Movement Wrestling: American Labor's Enduring Struggle With Immigration, I 866-2007”, Studies in American Political Development, 23 (2009), pp. $84-\mathrm{II} 3,87-88$.

34. Gerald Grob, for instance, labels opposition to immigration as the one exception to the Knights' "hope of unifying all workers regardless of race or sex"; Gerald Grob, Workers and Utopia: A Study of Ideological Change in the American Labor Movement, I865-I900 (Chicago, IL, I969), pp. 58-59.

35. Isaac Hourwich, Immigration and Labor: The Economic Aspects of European Immigration to the United States (New York, I9I 2).

36. "Testimony of T.V. Powderly", p. 497.

37. JUL, 9 October I 890.

38. Proceedings of the GA, I887, pp. I $835^{-1} 842$. 
As well as encouraging nativism and national chauvinism, immigrants could foster more cosmopolitan attitudes amongst other unionists, and promote greater awareness of, and interest in, foreign affairs. This cauldron of expatriates and their politics in the cities of the United States also resembled another city, at another propitious time in the history of international labour. London, as Susan Milner writes, was a "minor International" in its own right during the middle decades of the nineteenth century. The city drew political refugees and migrant workers from across the continent just as the United States was to do on such a dramatic scale in the latter decades of the century. Out of their ranks came much of the impetus behind the First International. ${ }^{39}$

There are other parallels between the International and the Knights. London's trade unionists, the other key participants in the International, suffered as employers increasingly imported foreign workers to break strikes, force out union men, and drive down standards. "In the short term", Milner argues of the London unionists, "international links could be used by British workers as a means of creating solidarity and thus dissuading foreign workers from taking jobs in Britain during strike movements". ${ }^{\circ}$ American labour also viewed international engagement as a defensive measure designed to curb foreign strike-breaking and regulate harmful migration. The Order's predecessors had forged numerous international links, particularly with British unions, towards these ends. The high point of these attempts came when A.C. Cameron, editor of the Chicago Workingmen's Advocate, went to the First International's Basel Conference in I869 as the emissary of William Sylvis and the National Labor Union, the first truly nationwide body representing American labour, primarily to urge the international regulation of emigration to the United States. ${ }^{41}$ The Conference created an Emigration Bureau for this purpose. As Samuel Bernstein writes, however, it "very likely remained a paper body". ${ }^{2}$

The Knights continued and expanded upon this tradition of international interaction. As early as I 880 , Powderly began correspondence with the miners' leader and Lib-Lab MP Alexander MacDonald with a view to greater cooperation between their two organizations, asking that year's General Assembly to "do something whereby the benefits of a union between the workingmen of America and Europe may become so plain that a connecting link may be forged, binding them closely together". ${ }^{43}$

39. Milner, Dilemmas of Internationalism, pp. $2 \mathrm{I}-22$.

40. Ibid.

4I. Lane, Solidarity or Survival?, p. 49; Henryk Katz, The Emancipation of Labor: A History of the First International (New York, 1992), pp. 60-63.

42. Samuel Bernstein, The First International in America (New York, 1965), pp. 33-34.

43. Proceedings of the GA, I880, p. I75. 
After an initial flurry of activity, Powderly and McDonald's exchanges ceased until the former in I885 again contacted the latter's successor, Thomas Burt, suggesting closer and more formal cooperation between their respective organizations. This suggestion ultimately came to naught. ${ }^{44} \mathrm{But}$ Knights also tried in other ways to use international engagement as a means of encouraging the voluntary regulation of immigration. Behind these attempts lay their belief that the contract labour law was easily evaded, and that the federal government was a lukewarm ally, at best, in the enforcement of that law.

When the US Ambassador to Britain told audiences there in 1885 of the plentiful jobs awaiting emigrants in the United States, Powderly demanded that he "should return to his own country for a while", study American conditions, "and then go back to his post to represent, and not misrepresent, us in a foreign land". But this was not all. As well as insisting that existing immigration laws should not be tampered with, Powderly recommended that the Order enter into correspondence with as many European labour organizations as possible, asking them to "publish statements of the conditions of affairs in this country". Even more, Powderly suggested that the Knights "print circulars and documents concerning the status of the workingman here, and scatter them among our brethren in foreign lands". ${ }^{45}$ This, indeed, was the natural outgrowth of similar warnings circulated within the United States: the Journal of United Labor regularly reprinted notices from various localities warning of a glut of workers there. Knights would thus use their international connections and assemblies to counter the misstatements of emigration agents and public figures, and convince foreigners to remain at home at times when labour markets were overstocked in the United States. A writer in the Order's journal put this sentiment in general terms. "International correspondence and co-operation of the labor organizations of all civilized countries", he wrote, "will be a better means to restrict the evils of unwelcome immigration to this country than the hypocritical execution of laws made by the representatives of the capitalistic class". ${ }^{6}$

The idea of Knights as anti-emigration agents was a popular one. J.F. Duncan, a Detroit Knight, wrote in I 886 to the Aberdeen Trades Council concerning the recent arrival in Duncan's city of a number of masons from Aberdeen. The "labour war was being fought there for all it was worth, to uphold a higher scale of wages and shorter hours", he explained, "and yet men from Aberdeen were so contemptible as to do the "scab act". 
The remedy lay in the introduction of a new body to regulate migration. "The Aberdeen Trades Council should organize an assembly of knights of labour", Duncan suggested, "and so avoid in future the occurrence of such a thing as had just happened". ${ }^{47}$ Knights on strike in the Toronto building trades, on at least one occasion, went one better than Duncan and actually sent delegates over the Atlantic to convince English workers not to emigrate. ${ }^{4}$

And even when the Washingtonian Knight Paul T. Bowen addressed the "Possibilist" International Labour Congress at Paris in I 889, his main concern was the immigration question. "It was difficult", ran the Times's account of his speech,

[...] to obtain improvements by the action of trade unions because of the constant influx of immigrants. He urged that the many dishonest misrepresentations made by emigration agents ought to subject such men to severe penalties. The workers of Europe would win the sympathy and support of the Americans if they would take up the question of emigration. ${ }^{49}$

The Congress's resulting resolution on immigration passed by unanimous vote but, like the emigration bureau proposed at the First International's Basel Conference, lacked practical teeth. ${ }^{50}$ Bowen's words nevertheless speak to Knights' desire to impose order, through international workingclass cooperation, on otherwise harmful and uncontrolled flows of people across national borders.

This same understanding also led the Order into its first major organizing venture abroad. And it was the same Knights who most stridently called for the prevention of contract labour, the window-glass workers of $\mathrm{LA}_{3} 00$, who provided the funds and manpower. These two parallel strategies could, and indeed did, aim at the remedy of a single cause. Local Assembly 300 , described by one scholar as "the most powerful labor organization in the history of the United States" because of its powerful hold over the window-glass industry, had managed to impose on glass manufacturers a medley of rules and regulations regarding working conditions. ${ }^{\text {II }}$ Its members enjoyed an unbroken vacation through July and August, successfully resisted attempts to introduce automation into the industry throughout the nineteenth century, maintained strict guidelines concerning the number and proportion of apprentices, and organized every craft in the making of flat glass. The Assembly could also

47. Aberdeen Weekly Journal, I3 May I 886.

48. Sheffield and Rotherham Independent, 8 June 1888.

49. The Times, i 8 July i 889 .

50. JUL, is August I889.

5. Pearce Davis, The Development of the American Glass Industry (Cambridge, MA, 1949), p. I 26. 
draw on impressive cash reserves, which by the mid-I 890 amounted to over $\$ 60,000$ as well as a number of stockholdings. ${ }^{52}$ But with the contract labour law proving a blunt instrument, foreign glassworkers brought in by employers still threatened the closed shop they maintained across the United States.

The Assembly lobbied Congress for the further regulation of immigration and for a protectionist tariff on imported glass. But they went further than this. As early as i $880, \mathrm{LA}_{3} 00$ sent two members to Europe to investigate the possibility of joining American with European glass workers, visiting England, France, Germany, and Belgium. In June I 884, Isaac Cline and Henry Burtt, the Assembly's President and Secretary respectively, held a convention of French, Belgian, and Italian glass workers and brought the Universal Federation of Window Glass Workers into being. With the financial aid of the General Executive Board, the glass workers sent A.G. Denny to Europe in September to bring these craftsmen into the Order. With Denny organizing the glassworkers of Sunderland and Charleroi, while also bringing workers in a variety of other crafts into the Order, the GEB's annual report claimed that "the seed is thus sown in England and Belgium, which will ere long bear abundant fruit". ${ }^{53}$ LA 300 subsidised the Universal Federation's activities and those of its constituent organizations until the turn of the decade, while the Knights as a whole paid the expenses of the Federation's Belgian secretary, Albert Delwarte, who clocked up the most mileage of any Knights organizer in 1888 .

Discerning the motives behind LA 300 's international strategy is not difficult. The Assembly withdrew from the Federation in I 890 , effectively consigning it to the scrapheap, due to an inability to organize successfully at the Pilkingtons' glassworks in St Helens, the largest and most direct competitor with American glass manufacture. Foreign glassworkers were at least partially correct in their resentment of the Federation as primarily intended to keep them from emigration to the United States. ${ }^{54}$ American glassworkers certainly saw the Federation in something like this way. "LA $300, \mathrm{~K}$ of L, window-glass workers", ran one of the Assembly's resolutions in I889, eschewing all sentimentality, "has had occasion to use the benefit of the Universal Federation of Labor in order to protect the interest of LA 300 and its members".55 In these terms, internationalism was but another tactic for glassworkers to maintain their closed shop. But that would be to ignore the many foreign craftsmen who LA 300 helped to

52. Quentin R. Skrabek, Michael Owens and the Glass Industry (Gretna, LA, 2006), pp. 38-39; Proceedings of the GA, I896, p. 27.

53. Pelling, "Knights of Labor in Britain", pp. 3I4-315; Proceedings of the GA, I885, p. 55.

54. Pelling, "Knights of Labor in Britain", p. 3 I 8; Proceedings of the GA, 1888, pp. 57-58.

55. JUL, I August I 889 . 
settle in the United States, so as to ensure that new glassworks would be run on union lines. The Assembly regularly brought over Belgian glassworkers to fill new positions in the United States; as late as April I 889, English glassworkers departed for "good situations" in American works with the express aid of LA $300 .{ }^{56}$

The history of the Universal Federation thus provides part of the answer as to how the same unionists could favour both immigration restrictions and organize potential immigrants overseas. Knights did not seek to shut out all immigration. They sought instead to regulate immigration to ensure that their own interests were not harmed, and attempted to do this through legislation directed at what they saw as unwanted types of immigration, particularly contract labour. There were, indeed, racial considerations that directed their ire towards particularly nationalities, of which the Chinese, other Asians, and those from the industrial peripheries of southern and eastern Europe were the most common. Nor were these considerations negligible. But it was the desire to achieve the regulation of migration that was most important in driving the Knights, particularly through the vehicle of Local Assembly 300, towards international action.

$\mathrm{LA}_{3} 00$, however, was only one component, if an important one, of the Knights and their international history. In the same way that the desire to regulate immigration was only one part, if a crucial one, of the Order's internationalism. The other part, as the Knights called it, was Universal Brotherhood.

\section{INTERNATIONALISM AS BROTHERHOOD}

In 1887 , General Secretary Charles Lichtman replied to an inquiry from Australian trade unionists eager to bring the Order "Down Under". Enclosed with copies of the Knights' preamble, constitution, and other documents came a note from Lichtman, who wrote of the Order's mission that "the object we are working for is to embrace all toilers, whether hand or brain, into one vast Brotherhood, and to endeavour to put an end to one trade fighting against another" ${ }^{57}$ Eight years earlier he had expressed much the same sentiment at greater length. He told representatives at the 1879 General Assembly:

The broad principle of Universal Brotherhood which our Order teaches gives us a platform so broad and comprehensive that all honourable toil can stand thereon, and work heart and soul together for the emancipation of Labor, and when the day shall dawn that United Labor shall move together to secure the

56. Ken Fones-Wolf, "Immigrants, Labor and Capital in a Transnational Context: Belgian Glass Workers in America, I880-1925", Journal of American Ethnic History, 21 (2002), pp. 59-80, 64-67; Smethwick Telephone, 20 April i 889.

57. Brisbane Courier, 5 September 1887. 
triumph of cooperation, a peaceful revolution will have been accomplished, and mankind brought nearer to Him after whose image man was created. ${ }^{58}$

To Lichtman and other Knights this "one vast Brotherhood" dissolved divisions based on craft, race, nationality, and even gender. It also crossed national borders, and was a truly international faith.

The language of Universal Brotherhood was a popular one in latenineteenth century labour circles, possibly more widespread, as Robert Weir argues, than now familiar notions of class solidarity. ${ }^{59}$ Advocates of the latter used the language of the former. The British socialist John Ward, for instance, described socialism as the "Universal Brotherhood of Man"; his compatriot Annie Besant, indicating that brotherhood was at least ambiguously gendered, talked of "the transformation of Class Society into a Brotherhood of equal Workers". ${ }^{60}$ Earlier American trade unionists also deployed similar rhetoric. William Sylvis, speaking of the suffering of locked-out English workers in the r860s, saw the solution as "the united and fraternal agency of our organs of labor". ${ }^{61}$ The short-lived International Labor Union, led by future Knight George MacNeill, strove in his words "to band together Jew, Greek, Irishman, American, English and German, and all nationalities in a grand labor brotherhood" ${ }^{62}$ Even Adolphe Strasser, the cigar-makers' leader and future paragon of pure-and-simple unionism, could declare after an English strike that "we will strive to unite all the trade and labor unions in both hemispheres into one International Brotherhood". ${ }^{3}$

But more than perhaps any other labour organization in the late nineteenth century, or at least those of major significance, the Knights of Labor made the rhetoric of Universal Brotherhood their own. Their fidelity to this ideal was, of course, uneven. A.T. Lane, writing of American unionists' attitudes towards immigration, divided them into "enthusiasts", those whose understanding of solidarity knew no distinction of race, nationality, or gender, and for whom this understanding approached the unquestioning conviction of religious faith; and "instrumentalists", those whose understanding of solidarity was restricted to the immediate needs of strikes and other struggles. ${ }^{64}$ Enthusiasts, for my purposes, include

58. Proceedings of the $G A$, 1879 , p. 63.

59. Weir, Knights Down Under, p. 235.

60. John Ward, Socialism: The Religion of Humanity (London, I889), p. I2; Annie Besant, The Trades Union Movement (London, I 890), p. 3.

6r. William Sylvis, The Life, Speeches, Labors and Essays of William H. Sylvis (Philadelphia, PA, I 872), pp. $455-456$.

62. Philip S. Foner, History of the Labor Movement in the United States, I (New York, I947), p. 502 .

63. Yearley, Britons in American Labor, pp. 60-6I.

64. Lane, Solidarity or Survival?, pp. 6I-67. 
those who created and took the Order's message about Universal Brotherhood seriously, and as with those of Lane's description, most likely constituted a minority within the Order. They did, however, probably make up a majority of the Order's leaders from Uriah Stephens through to Powderly. Many Knights paid little attention to Powderly's pronouncements, and many actively opposed his leadership, whether they were anarchists, socialists, or even traditionalists who felt that the GMW's relaxation of the Order's secrecy had betrayed its origins. But the enthusiasts had a potent platform in the Order's machinery of government and its press. They also had much control over the decision-making processes, not to mention the funds, necessary to put international work into motion. Thus, while it is impossible to speak of the Order as a single, homogenous entity - in composition or ideology - we can view leading Knights as coherent enough in their adherence to the idea of Universal Brotherhood.

Knights derived their commitment to Universal Brotherhood from a number of sources, all of which had internationalist implications. The first of these were the Order's rituals and symbols, many of them loosely plagiarized from other fraternal orders, particularly the Oddfellows, the Knights of Pythias, and the Freemasons. The Grand Master of a Masonic Lodge, and the Master Workman of a Knights' Assembly, for instance, both originally presided over "noble brothers" with an open Bible and very similar signs and rituals. Uriah Stephens and other early Knights adapted these rituals and symbols as pedagogical devices that would, through repetition, foster solidarity amongst their members. ${ }^{65}$ This solidarity was intended to be international. Thus, as newly initiated Knights would be told by the assembly's Venerable Sage, the globe, placed at the entrance to the assembly hall to show to initiates that the assembly was in session, possessed a deeper if obvious meaning. "The symbol of the Outer Veil is a Globe, symbolizing the field of our operation", the Sage would inform the neophyte, "and signifies 'Universal Organization”' ${ }^{66}$ The Order's Great Seal provided similar reinforcement. The Seal shows a partial map of the globe, with the triangle at its centre focused on the Americas but extending towards Australasia. The pentagon surrounding this map represented the "five races of men", from each continent, all looking to the Order for guidance. ${ }^{67}$ A secret circular explaining all these symbols, and intended to be read out once a quarter year in every Local Assembly, left little room for misinterpretation. ${ }^{68}$

65. Robert Weir, Beyond Labor's Veil: The Culture of the Knights of Labor (University Park, PA, 1996), pp. 26-27.

66. Knights of Labor, Adelphon Kruptos (Chicago, IL, I886), p. I3.

67. Weir, Knights Down Under, p. 205.

68. Terence V. Powderly, The Path I Trod: The Autobiography of Terence Powderly (New York, 1940), pp. $43 \mathrm{I}-443$. 


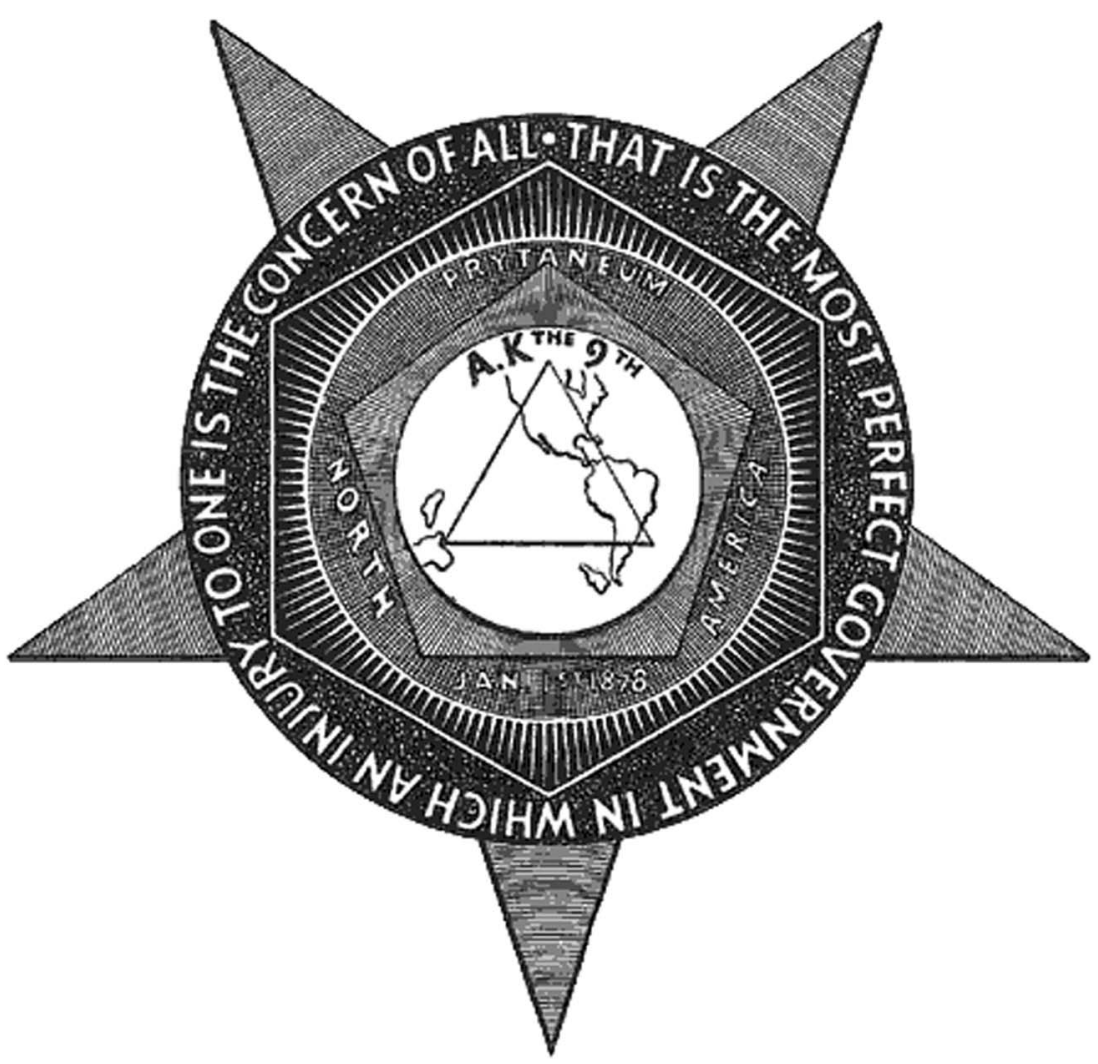

Figure 2. The Great Seal of the Knights of Labor. In some versions of this symbol the triangle at the centre extends to a series of small islands to the west, most likely representing Australia. The date below the pentagon refers to the Order's first General Assembly. "A.K. the 9th" refers to the Adelphon Kruptos, the secret book of the Order's ritual, and to the fact that the first General Assembly of the Knights was held nine years after the Order's founding in I 869. http://mill-valley.freemasonry.biz/fraternal-images/the_great_seal.gif

To Stephens, moreover, these rituals served more than simple educational purposes. For him the Order's object, that of "knitting up into a compact and homogenous amalgamation all the world's workers in one universal brotherhood", would be accomplished if they were "guided by the same rules, working by the same methods, practicing the same forms for accomplishing the same ends". ${ }^{69}$ Shared ritual would thus foster brotherhood in practice as well as in thought amongst diverse groups of wage earners, both in the assembly hall and on an international scale. 
Alongside and in conjunction with this emphasis on the unifying effects of fraternal practice, Knights derived universalistic conclusions from the particular brand of Christianity that pervaded the Order's rituals and symbols, and animated its founders. Again it was Stephens, who had briefly flirted with the idea of joining the Baptist ministry in his youth, who was largely responsible here. Knights seeking to uphold the sanctity of labour emphasized Jehovah's punishment to Adam in Genesis, "In the sweat of thy face shalt thou eat bread". The same kind of religious feeling also provided a powerful argument for solidarity across national, ethnic, and colour lines, mirroring the radical Protestantism that underlay much of antebellum Abolitionism. Stephens's "one universal brotherhood”, he wrote, "builds upon the immutable basis of the Fatherhood of God and the logical principle of the Brotherhood of Man" ${ }^{\circ}$ Shared practice in the assembly hall, and the equality of all men in the eyes of God, were both seen by Knights as powerful inducements to internationalism.

As Stephens, if not all subsequent Knights, envisaged it, Universal Brotherhood meant solidarity based on mystical and spiritual as well as material sources. It was also a product of the political tradition which historians now term "labour republicanism". Labour republicanism, as Leon Fink has explained, was rooted in artisanal traditions emphasizing the worth of the independent producer. It stressed the nobility of toil through an understanding of the labour theory of value which, though lacking the Marxist-style concept of surplus value, nevertheless still demanded for the worker an equitable fraction of the wealth he or she produced. Labour republicanism likewise emphasized pride in American republican institutions while warning that the growth of monopoly and concentrated capital threatened their survival. ${ }^{7 \mathrm{I}}$

This represented the continuation of an earlier Anglo-American radical tradition, whose early figures were Tom Paine and Thomas Jefferson, and whose successors included the British Chartists, the American land reformers of the I 850 , and such formative figures in the intellectual development of Uriah Stephens and his generation as the writer and reformer, George Lippard. Indeed, Lippard's own organization, the Brotherhood of the Union, which from i 850 combined religious and fraternal inspirations with a struggle against "corrupt Bankers, against Land Monopolists and against all Monied Oppressors", is credited as the direct precursor of the Knights of Labor itself. ${ }^{2}$ Knights did their best consciously to adapt, or least update, this tradition to the problems of late nineteenth-century industry. The emphasis of this tradition on the unity of all producers indeed found its

7I. Leon Fink, Workingmen's Democracy: The Knights of Labor and American Politics (Urbana, IL, 1983), pp. 3-5.

72. David S. Reynolds, George Lippard (Boston, MA, 1982), pp. I9-2 I. 
most popular expression in the Knights of Labor; it also carried strong connotations, as with Marxist ideas of class interest, of unity as international as well as national in scope.

The solution Knights sought for the ills of contemporary society, the always vaguely defined cooperative commonwealth, had similar implications. The triumph of cooperation, as the report of one local assembly insisted in I882, must occur on a global scale as "the co-operation of only a limited number of individuals will not result in the triumph of the co-operative principle all over the globe; it would only improve the condition of those who were participants in the respective enterprises, for a short time". ${ }^{73}$ Others put the question in even starker terms. "Individualism must go, or humanity will perish!", claimed one entry in the Journal of the Knights of Labor. "Universal brotherhood, scientifically organized, is our only salvation", it continued, calling for the somewhat clumsily phrased "Commonwealth of the Universal Republic of Labor and Fraternal Reciprocity". ${ }^{74}$

Similar millennial language also pervaded the education campaigns which Knights attempted throughout the r 880 os and into the I890s. The "Spread the Light" campaigns, as they were called, were designed to bolster existing discussions of political economy at the local assembly hall. These were largely restricted to the United States and Canada, though English assemblies at least gave very generously to one of the Order's periodic Special Educational Funds.75 But for the true believer in the Order's message, "spreading the light" was an almost religious imperative that did not recognize the sanctity of national borders. ${ }^{76}$ For instance W.W. Lyght, the man whose agitation proved crucial in setting up assemblies in New Zealand and Australia, was as much a missionary for the Order overseas as he was its organizer. ${ }^{77}$

The Knights' conception of Universal Brotherhood was thus an amalgam of economic, political, religious, and fraternally based ideas and concerns. With all these ideological commitments it is not surprising that many Knights thought of themselves as internationalists, and of their Order as international in scope. By organizing under the banner of Universal Brotherhood, moreover, many Knights were forced to couch what might otherwise have been openly racist arguments against the "new" immigrants in the language of free as against unfree labour. As A.T. Lane argues, this commitment to solidarity was instrumental in steering them towards the more limited and ultimately rather ineffective contract labour law instead

75. Ibid., 26 July I 888; 9 August I 888; 23 August I 888.

76. Kealey and Palmer, Dreaming of What Might Be, pp. 277-329.

77. For Lyght's enthusiasms, see especially Weir, Knights Down Under. 
of agitating for a more general ban on immigration, even if Powderly did eventually call for a ten-year freeze on new immigrants. ${ }^{78}$ Brotherhood could indeed prove a powerful, if limited, check on xenophobia. After the I 885 massacre of Chinese miners at Rock Springs, Wyoming, a surprising number of representatives at the next General Assembly - forty-two out of ninety-five - even put themselves on record in favour of organizing some Chinese workers, narrowing that particular gap in their solidarity. ${ }^{79}$ Knights could and did wheel out brotherhood as a defence for very unfraternal and even murderous, racially inspired actions. It could also temper, however, with varying degrees of success, the prejudices that lay behind the horrible events of Rock Springs and elsewhere.

But the synthesis between Universal Brotherhood and opposition to unregulated immigration did not just run one way. Just as Knights' ideological commitments tempered and modified their opposition to uncontrolled immigration, that opposition was the prism through which Knights went about turning Universal Brotherhood from word into fact. Indeed, they hoped that through the extension of Universal Brotherhood they might solve the problem of immigration itself. "We must gain a foothold in all of the European countries", Powderly told the I 884 General Assembly, having just discussed the subject of immigration restrictions, "and, by organization, teach the people of these lands that there is no truth in the representations of those who would allure them from their homes. We must endeavour to impart to other nations the benefits which we derive from education, agitation and organization."

The GMW was not the only one who saw international solidarity in these terms. A resolution from District Assembly Io4 of New York, at the I 886 General Assembly, condemned "all legislation tending in any way to adjust American labor to foreign standards and conditions". But in the same breath as desiring to "exclude both pauper labor and the products of that labor from our shores", DAio4 spoke of the urgent necessity of "placing our organization in communication with the labor societies of Europe for the purpose of preparing the way for a General Assembly of the workingmen of the world". Its object, the Assembly's representatives explained, would be in "seeking to uplift labor everywhere to the highest plane, and resisting the tendency of the times to drag it down to the lowest". ${ }^{81}$ Charles Lichtman argued on similar lines in I 888:

When the Knights of Labor and kindred organizations shall have obtained in foreign lands the same commanding position and influence enjoyed in the

78. Lane, Solidarity or Survival?, ch. 2.

79. Fine and Tichenor, "A Movement Wrestling", pp. 93-94.

80. Proceedings of the GA, 1884, p. 576 .

8I. Proceedings of the GA, I886, pp. 202-203. 
United States, the inequality of wages will disappear, not by levelling our wages down but by levelling their wages up. It is far better to level up than to level down, as the larger the income the larger the power to consume. ${ }^{82}$

On the one hand, then, Knights viewed Universal Brotherhood as a powerful spur to transnational organizing on its own terms. On the other they viewed the spread of Universal Brotherhood as a means to raise living standards elsewhere up to American standards. Equalizing the wages of American and European workers would render immigration to the United States unnecessary, and workers on both sides of the Atlantic would benefit accordingly. Powderly provided the best and most detailed explanation of this synthesis, linking idealistic and practical considerations together, in an I 888 article which referred to the anticipated horde of new arrivals as a "menacing eruption". "The Knights of Labor, as an organization, is spreading throughout the world", he wrote in I888,

[...] and its principal feature is to teach its members and others that the land in which a man is born owes him something more than oppressive laws and unjust restrictions which prevent him from earning a living. In every country abroad that organization is to place a declaration of principles before the people, selecting some particular feature around which to rally. The members are to be taught to reform existing abuses at home, so that emigration for the purpose of bettering their lot will not be necessary; they are to be taught that the right to enjoy life in the land of his birth is inherent in man. Once these doctrines begin to spread abroad the people will begin to take more of an interest in home affairs. To assist foreigners to improve their condition at home, it is not necessary to reduce our own people to a condition bordering on serfdom by loading us down with a helpless surplus population which can at best be used only to the advantage of monopoly. ${ }^{, 83}$

Actuated by ideals of Universal Brotherhood, Knights were willing to help workers abroad to improve their conditions of life. This aid was contingent, however, on foreigners remaining at home to fight there for better living standards, democratic rights, and for the Order itself. Knights would practise brotherhood - but they would do so from a distance.

\section{CONCLUSION: INTERNATIONALISM AS AMERICANIZATION}

"Patriotism", wrote George Orwell, "is usually stronger than class hatred, and always stronger than any kind of internationalism". ${ }^{84}$ Studies of labour internationalism, while not always endorsing this thesis, acknowledge that nationalism could often prove a dominant and overbearing force in all

82. Wichita Daily Eagle, I3 September I 888.

83. T.V. Powderly, "A Menacing Irruption", North American Review, August I888, pp. I65-I74.

84. George Orwell, “The Lion and the Unicorn”, Essays (London, 2000), p. I46. 
international labour organizations. The move by virtually all constituent member parties of the Second International from issuing resolutions condemning and opposing war in I9I0, to the voting of war credits in I9I4, represents only the most notorious example of this force in action. Yet patriotism could inform and reinforce as well as hinder internationalism in thought and deed. David Felix, for instance, has shown how Marx made use of nationalistic sentiment in building the First International. ${ }^{85}$ The same was true of the Knights of Labor.

Knights combined what they saw as patriotic opposition to unregulated immigration with their attachment to Universal Brotherhood. They preached brotherhood, in other words, from a distance. This synthesis, which helped lead the Knights in their unprecedented organizing work on four continents, transcending linguistic as well as political borders, was also derived from a particular understanding of America's relationship with the Old World. American workers, Knights generally held, enjoyed higher wages, greater freedom from political repression, and more political options through legislative means than their European counterparts. Paul T. Bowen, reporting back from his European excursions in I889, made this point especially strongly. ${ }^{86}$ In organizational terms, moreover, Knights saw themselves as far in advance of organized labour elsewhere. "Our field of labor is the globe", claimed Missourian Knight F.D. Jones; listing the Order's overseas outposts, he argued that Knights imparted "a better knowledge to the toilers of all these countries of the condition of their brothers and sisters, irrespective of creed or nationality. No other organization has done this." ${ }^{87}$ Many foreigners from all over the world agreed. Visiting French deputy Paul Deschanel, for example, claimed even in I 892 that "the perfection of labor organizations here is years, I may say dozens of years, in advance of anything which has been dreamed of in France". ${ }^{88}$

Labour in the United States, many Knights believed, thus had a special opportunity and obligation, even a patriotic duty, to organize abroad. "In other countries", claimed one, "the working classes are bound down so that they have not the power to extricate themselves from the tyrannical powers of emperors, kings, queens, and employers". The labour question, he continued, "can never be solved in Europe. The boundaries there are too limited for it to assume the fullness of proportion" which could "permit of its being put to a practical test". ${ }^{9}$ "The emancipation of European workers, in this view, depended on the victories and aid of their American

85. David Felix, "The Dialectic of the First International and Nationalism," Review of Politics, 45 (1983), pp. 20-44.

86. JUL, I4 November I 889.

87. Ibid., I 3 December 1888.

88. Ibid., 28 April I892.

89. Ibid., 25 June I 886. 
counterparts. As this Knight also insinuated, their emancipation would also be hastened through the adoption of American-style republicanism.

This patriotic belief in the superiority of American republicanism over all other political systems was a very popular one amongst the Order's leaders. Powderly wrote of the American flag that it would "illumine the pathway over which [...] Latin, Teuton, Celt and Slav shall unite to proclaim liberty and brotherhood throughout the world and to all the men and women of earth". ${ }^{\circ} \mathrm{He}$ claimed of the Declaration of Independence, which he hoped would hang on the walls of every Local Assembly hall, that "it is true that it was born in America, but it grew for all men and belongs to all nations". ${ }^{\mathrm{I}}$ $\mathrm{He}$ also rejoiced that changes by foreign Knights to the Order's Preamble and Declaration of Principles, which he often likened to the Declaration of the Founding Fathers, "were but few; the parts of our Preamble which did not apply were fewer still". ${ }^{2}$ Both the Knights and American republicanism, he considered, were ready for export together. The Order would then, to coin a phrase, Americanize the world.

The Americanization movement is largely associated with government and quasi-government policy during World War I. Faced with large numbers of immigrants from hostile countries, a potential fifth column able to disrupt the war effort and even facilitate invasion by an enemy power, those in government and business attempted to acculturate newcomers in American customs and beliefs. But as James Barrett has shown, the American labour movement, whether consciously or unconsciously, also tried to Americanize its prospective immigrant members. ${ }^{93}$ For the unions, Americanization meant acclimatizing immigrants to a higher standard of living, and teaching them the self-respect on the job necessary to become a "union man". Many unionists, Knights included, doubted whether the newer arrivals, increasingly from areas where industry and union action were still new or unknown, would ever be properly assimilated in this respect. ${ }^{94}$ Yet despite these suspicions, and often in the face of their own xenophobic beliefs, Knights were in the forefront of attempts to transform new immigrants into American unionists. ${ }^{95}$

But the Knights also took this process of Americanization a step further. Just as the Window-Glass Workers sought to use their Universal

90. Powderly, Path I Trod, p. 97.

91. Proceedings of the $G A$, I887, p. I538; i 885 , p. i 8.

92. Proceedings of the $G A, \mathrm{I} 890, \mathrm{p} .3$.

93. James Barrett, "Americanization from the Bottom Up: Immigration and the Remaking of the Working Class in the United States, I880-1930”, Journal of American History, 79 (1992), pp. 996-1020.

94. Montgomery, Fall of the House of Labor, pp. 70-82.

95. Philip S. Foner, History of the Labor Movement in the United States, II, (2nd edn, New York, 1975), pp. 57-58. 
Federation as a complement to legislative restrictions on immigration, Knights sought to create union men out of would-be immigrants overseas in order to prevent their arrival in the United States. In doing so, as Charles Lichtman pointed out, they would "level their wages up" to American levels. Otherwise, as Knights repeatedly explained, American labour would be levelled down to European standards to the detriment of Americans and Europeans alike. "We can better afford to aid the European in battling down the institutions which crush him at home", said Powderly in I892, "than to continue a system which will inevitably reduce our own workmen to worse conditions than those now experienced abroad by people who are looking to this land for relief". ${ }^{6}$ As the GMW explained elsewhere, unchecked immigration also threatened to weaken the feelings of brotherhood that inspired Knights to organize their overseas brethren:

If two brothers in a starving condition find a crust of bread they rush forward to clutch it, and in the scramble they give no heed to the laws of consanguinity; the ties which bind men together closer than those which are formed through friendship or birth are forgotten, and but one law is observed - the law of "self preservation". ${ }^{97}$

Extending brotherhood would limit immigration; limiting immigration would preserve the idea of brotherhood. Through this equation Knights not only synthesized but justified their hostility to various kinds of immigration, while at the same time keeping their faith in Universal Brotherhood and without merely being guilty of cognitive dissonance. In the same way, through attempting their unique kind of Americanization, Knights also reconciled nationalism and internationalism without sacrificing the latter. They certainly did not view these two concepts as mutually exclusive opposites. "He is the true internationalist", Powderly insisted in his later autobiography, "who is really and sincerely a nationalist". ${ }^{8}$ Indeed, as with most of the Order's activities, Knights framed internationalism in nationalist ways, and for nationalist reasons. Patriotic pride in American institutions not least of which was in their own - encouraged them to organize abroad. Their fear that these institutions were under threat, far from only leading Knights towards simple restrictionism and nativism, also further encouraged their international work. Patriotic pride, and patriotic fears, both pointed in internationalist directions.

Of course, unresolved contradictions remained. Knights' opposition to immigration centred, in addition to contract labour, on the "new" immigrants, those from southern and eastern Europe. Yet their international activities did not centre on these countries: quite the reverse. 
All of the Order's overseas assemblies, with the exception of a handful in Italy, were in countries associated with the "old", "voluntary", immigrants. Was this the product of lingering racial antipathies, despite the fact that Knights at one point or another organized amongst all the new immigrants, even, in some cases, amongst the Chinese? This was certainly true to an extent. But linguistic difficulties were important as well. The Order did print its literature in a number of different languages, and Powderly himself approved foreign-speaking lecturers so long as they exhorted their audiences to learn and conduct union business in English. ${ }^{99}$ Sending some of these multilingual lecturers overseas, however, was a risky and extremely expensive business; and while the Knights were never short of enthusiasm they were always desperately short of cash.

These limitations should also not distract us too much from the significance of the Order's global achievements. In light of recurrent financial problems, time-consuming internal battles, and relentless employer opposition, the fact that any international organizing occurred, regardless of its limits, was impressive enough. The Second International, for instance, had considerably greater resources than the Knights, and did not generally face the same level of repression from employers or states. But just as Knights failed to organize in southern and eastern Europe, the International, almost exclusively a European body and strongest in the imperial countries, had an unenviable record concerning the colonies over which these same imperial powers ruled.

Knights were not alone, then, in claiming a universal mandate while undercutting this in practice. Just as with many socialists trying to live up to the international proletarian solidarity that they expressed, however, many Knights transcended some of their own prejudices simply by trying to live up to their calls for Universal Brotherhood. In practice, of course, their talk of brotherhood was often limited. Their rhetoric often hid crude self-interest, or acted as a cover for inaction. But the Knights of Labor practised brotherhood on a world stage as well as preaching it, even if they did, in general, aim to practise this brotherhood from a distance.

\author{
TRANSLATED ABSTRACTS \\ FRENCH - GERMAN - SPANISH
}

Steven Parfitt. La fraternité à distance: l'américanisation et l'internationalisme des chevaliers du travail (Knights of Labor).

Le Noble et saint ordre des chevaliers du travail (Noble and Holy Order of the Knights of Labor) fut la plus grande organisation ouvrière du dix-neuvième siècle. 
Mais si les chercheurs ont retracé son histoire en Amérique du Nord, ils ont largement négligé d'étudier l'histoire de l'Ordre dans d'autres régions, même si cette organisation s'est enorgueillie d'avoir aussi des membres en Europe, en Australie et en Afrique. Cet article, conçu comme une partie d'une "transnationalisation" de l'histoire ouvrière américaine, analyse les raisons qui amenèrent les dirigeants de l'Ordre à leur croissance internationale. Les dirigeants des Chevaliers du travail envoyèrent des organisateurs dans le monde entier, tant à cause de leur attachement à l'idée d'une Confrérie universelle que comme moyen de limiter l'immigration aux États-Unis. Cette synthèse d'idées apparemment incompatibles reflétait leur désir d' "américanisation" du reste du monde, en protégeant le niveau de vie dans leur pays, en le haussant dans d'autres régions et en exportant à l'étranger les institutions républicaines de style américain.

Traduction: Christine Krätke-Plard

Steven Parfitt. Brüderlichkeit aus der Ferne: Amerikanisierung und der Internationalismus der Knights of Labor.

Bei dem "Noblen und Heiligen Orden der Ritter der Arbeit”, den Knights of Labor, handelte es sich um die größte amerikanische Arbeiterorganisation des I9. Jahrhunderts. Die Forschung hat zwar die Geschichte der Knights of Labor in Nordamerika rekonstruiert, ihre anderweitige Geschichte jedoch weitgehend vernachlässigt, und das obwohl die Organisation Mitglieder in Europa, Australasien und Afrika aufwies. Der Artikel ist als Teil einer umfassenderen "Transnationalisierung” der amerikanischen Arbeitergeschichte konzipiert; er analysiert die Gründe, aus denen sich die Anführer des Ordens für dessen internationale Ausdehnung entschieden. Wenn die Anführer der Knights of Labor Organizer in die ganze Welt entsandten, dann nicht nur, weil sie sich der Idee universeller Brüderlichkeit verpflichtet fühlten, sondern auch, weil sie darin ein Mittel sahen, die Einwanderung in die Vereinigten Staaten zu bremsen. In dieser Synthese scheinbar inkompatibler Ideen spiegelt sich ihr Wunsch, den Rest der Welt zu "amerikanisieren": durch die Verteidigung des Lebensstandards im eigenen Land und seine Anhebung auf amerikanisches Niveau in anderen Ländern sowie durch den Export republikanischer Institutionen amerikanischen Zuschnitts.

Übersetzung: Max Henninger

Steven Parfitt. Fraternidad desde la distancia: la americanización y el internacionalismo de los Knights of Labor.

La Noble y Sagrada Orden de los Caballeros del Trabajo fue la organización de trabajadores más importantes de Norteamérica en el siglo XIX. Pero mientras los investigadores han delimitado su historia en el ámbito norteamericano, poca atención le han prestado a explorar la historia de la Orden más allá de estos límites, aún cuando la organización hacía gala de tener miembros en Europa, Australasia y Africa. Este artículo se ha diseñado como parte de una "transnacionalización” más amplia de la historia sindical norteamericana y analiza las razones que llevaron a los líders de la Orden hacia su crecimiento internacional. Los líderes de los Knights of 
Labor enviaron delegados a diferentes partes del mundo no sólo por su implicación en la idea de la Fraternidad Universal, sino también como una vía de limitar la inmigración a los Estados Unidos. Esta síntesis de aparentes ideas incompatibles refleja su deseo de "americanizar" al resto del mundo, protegiendo los niveles de vida en casa, elevándolos a los niveles americanos allí donde fuere, y exportando el estilo americano de instituciones republicanas al extranjero.

Traducción: Vicent Sanz Rozalén 